\title{
EMPLOYEE MOTIVATION IN THE PROCESS OF MANAGING ORGANIZATIONAL CHANGE
}

\author{
Tijana Radojević ${ }^{1 *}$, \\ Tanja Stanković ${ }^{2}$ \\ Danica Rajin ${ }^{3}$ \\ ${ }^{1}$ Singidunum University, \\ Belgrade, Serbia \\ ${ }^{2}$ IRM Bor, \\ Bor, Serbia \\ ${ }^{3} \mathrm{FEFA}$, \\ Belgrade, Serbia
}

\begin{abstract}
:
The organizational changes on which the development of each organization is based depend on numerous factors and assumptions, but one of the most important is employee motivation. In this context, employee motivation is one of the crucial phases of the organizational change management process. Without successful motivation, all activities of this process lose their meaning and cannot be successfully implemented. This is the reason that employee motivation is increasingly in the focus of the theory and practice of organizational change management, as well as in the focus of consideration in this paper. The aim of this paper is the employee motivation in the process of managing organizational change. Specifically, the paper considers various aspects of motivation for organizational change as part of the organizational change management process.
\end{abstract}

Keywords:

employee motivation, organizational change, human resource management.

\section{INTRODUCTION}

Organizational changes are complex phenomena on which the development of each organization is based. They imply a series of different processes, procedures and events that need to be managed depending on many factors, but above all on their type and specificity.

Among organizational changes, the most complex are organizational transformations that imply and have many different aspects, of which the following stand out:

- Reengineering,

- Restructuring,

- Total quality management,

- Knowledge management programs,

- Customer relationship management programs,

- Innovation programs,

- Culture change programs and

- Learning programs (Grubić, 2011).

The transformation of the company, in contrast to the development of the organization, which is related to minor development changes, is related to radical revolutionary changes in the company. These are changes that affect the company as a whole, which are usually implemented in a relatively short period of time and lead to new organizational parts.

Today, in accordance with the turbulent environment, a continuous transformation of the company is necessary, which implies directing the organization towards high growth, large and significant changes.
Correspondence:

Tijana Radojević

e-mail:

tradojevic@singidunum.ac.rs 
In that context, change management is even more complex, and it is called transformational leadership, and if it is proactive, it leads to fundamental positive changes in the company (Džamić, 2016).

\section{MOTIVATION IN THE ORGANIZATIONAL CHANGE MANAGEMENT PROCESS}

Motivation in general is a force within a person that conditions certain instrumental actions in order to achieve set goals. Motivation from the point of view of members of an organization, i.e. employees, is seen by many authors as a process of satisfying individual needs which implies the following six steps (Cvetković, 2014):

1) Unmet need,

2) Tension,

3) Action,

4) Search,

5) Satisfaction of need,

6) Reduction of tension.

It is evident that unmet needs create stress and tension that drive action, and it further leads people to look for a way to achieve a goal that will meet their needs. This ultimately reduces the initial tension. From this model of the motivation process, it can be concluded that employees are always in a state of tension, and in order to get rid of that tension, they make efforts to meet the needs and reduce tension (Cvetković, 2014).

Motivation is especially important in the process of managing organizational change. In this context, the motivation of management and individual leaders is important, as well as the motivation of all members of the organization, i.e. employees.

One without the other does not lead to a successful change. This means that neither a motivated manager can make a change without motivated members of the organization, nor can motivated employees significantly contribute to a successful organizational change without a motivated manager.

Motivating employees and effective communication are closely linked to the effective implementation of organizational change. Factors of individual motivation include job satisfaction, an atmosphere of fairness, and organizational commitment. These factors are primarily realized through a work environment that is strongly influenced by organizational leaders. Leadership is deeply connected to the internal motivation systems of individuals. Therefore, the ability of a leader to cultivate a work environment that increases employee motivation proves to be a critical condition for the successful implementation of organizational change (Gilley, Gilley \& McMillan, 2009).

\section{MOTIVATION FOR CHANGE AND HUMAN RESOURCE MANAGEMENT}

Human resource management is a very special segment of the organization's management that is in specific relationships with other segments of the organization, starting from business strategy, change strategy, through all other strategies, all the way to employee motivation for both work and organizational change.

In the context of organizational change, human resources are the basis and the most important support for all changes. Every member of the organization is equally important in this context, whether they are change strategists, implementers or recipients of change.

Human resource management activities are conditioned by numerous organizational factors, and certainly depend on the types of organizational changes. The following is an overview of human resource management activities, as well as their advantages and disadvantages, depending on the three specific types of changes in the organization (Table 1).

Table 1. Types of organizational change and human resource activities

\begin{tabular}{|c|c|c|c|}
\hline Type of change & Human resource activities & Advantages & Disadvantages \\
\hline $\begin{array}{l}\text { Education and employee } \\
\text { involvement }\end{array}$ & $\begin{array}{l}\text { - management development } \\
\text { - employee training } \\
\text { - quality group programs } \\
\text { - joint consultations } \\
\text { - teamwork and communication } \\
\text { - employee counseling }\end{array}$ & $\begin{array}{l}\text { - a greater sense of } \\
\text { employee involvement } \\
\text { - getting fresh ideas } \\
\text { - longer-term change }\end{array}$ & $\begin{array}{l}\text { - lasts long } \\
\text { - slow process } \\
\text { - expensive } \\
\text { - resistance may arise due to } \\
\text { a negative attitude towards } \\
\text { change }\end{array}$ \\
\hline Workforce fluctuation & $\begin{array}{l}\text { - business interruptions } \\
\text { - redundancy programs } \\
\text { - recruitment and selection }\end{array}$ & $\begin{array}{l}\text { - significant impact } \\
\text { - speed }\end{array}$ & $\begin{array}{l}\text { - dealing with negative } \\
\text { consequences for employees } \\
\text { - probably an expensive } \\
\text { process }\end{array}$ \\
\hline $\begin{array}{l}\text { Changes in structures } \\
\text { and systems }\end{array}$ & $\begin{array}{l}\text { - changes in the organizational } \\
\text { structure and responsibilities } \\
\text { of employees } \\
\text { - changes in the reward system } \\
\text { - changes in the promotion } \\
\text { system }\end{array}$ & $\begin{array}{l}\text { - longer-term change } \\
\text { - renewal of knowledge } \\
\text { and skills in employees } \\
\text { - restoration of obsolete } \\
\text { systems }\end{array}$ & $\begin{array}{l}\text { - slower impact } \\
\text { - it can be difficult to } \\
\text { establish a direct impact } \\
\text { between these changes and } \\
\text { changes across the } \\
\text { enterprise }\end{array}$ \\
\hline
\end{tabular}


Of all human resource management activities, human resource planning most significantly depends on certain types of organizational change. The approach to human resource planning is different from the "status quo" situation in the organization, depending on whether the organizational change is planned or unplanned (Table 2).

Table 2: Types of organizational change and human resource planning

\begin{tabular}{|c|c|c|c|}
\hline Type of change & $\begin{array}{l}\text { Approaches in human resource } \\
\text { planning }\end{array}$ & $\begin{array}{l}\text { Strategic selection of } \\
\text { employees }\end{array}$ & Selection criteria \\
\hline Status quo & $\begin{array}{l}\text { Providing manpower for } \\
\text { existing jobs }\end{array}$ & $\begin{array}{l}\text { Selection based on } \\
\text { short-term expertise; the } \\
\text { possibility of dismissal if } \\
\text { the employee cannot fit }\end{array}$ & $\begin{array}{l}\text { Operational criterion: } \\
\text { attributes required for } \\
\text { successful performance of } \\
\text { work in the workplace } \\
\text { (knowledge, skills, interpersonal } \\
\text { skills, values) }\end{array}$ \\
\hline $\begin{array}{l}\text { Planned /anticipated } \\
\text { change }\end{array}$ & $\begin{array}{l}\text { Providing manpower for } \\
\text { projected future jobs }\end{array}$ & $\begin{array}{l}\text { Selection based on the } \\
\text { longer-term ability to } \\
\text { accept change, but taking } \\
\text { into account the risk } \\
\text { that employees will not } \\
\text { understand the change } \\
\text { due to limited } \\
\text { knowledge of the same }\end{array}$ & $\begin{array}{l}\text { Visionary criterion: attributes } \\
\text { that will hypothetically be } \\
\text { required in new jobs }\end{array}$ \\
\hline $\begin{array}{l}\text { Not planned / } \\
\text { no anticipated change }\end{array}$ & $\begin{array}{l}\text { Providing manpower for jobs } \\
\text { that cannot be described in } \\
\text { advance }\end{array}$ & $\begin{array}{l}\text { Follow the path of } \\
\text { constant modification in } \\
\text { the future, with } \\
\text { numerous changes in } \\
\text { employee selection } \\
\text { systems }\end{array}$ & $\begin{array}{l}\text { Transformation criterion: } \\
\text { attributes required to initiate } \\
\text { change; competencies for } \\
\text { change; rather than variable } \\
\text { competencies }\end{array}$ \\
\hline
\end{tabular}

Source: Dženopoljac, 2008.

In addition to the previously described relations between human resource management and organizational change, in the context of this paper, a significant link between human resource management and employee motivation for organizational change should be highlighted. Among the human resource management activities that most significantly affect employee motivation for organizational change are employee development and reward.

Employee development implies adequate conditions for learning during work with the aim of successful business operations of the company. It should be emphasized that the training of employees should be harmonized with the needs and goals of the company. In practice, the development of managers and employees is realized through various forms of acquiring new knowledge and skills.

Rewarding employees, which is carried out as an activity within human resource management, is a very important (but not sufficient) motivating factor for accepting organizational change by employees. It is important that the values on which a good reward system should be based are:

- justice,

- payment for performance,

- financial and non-financial rewards,

- Involvement of employees in the formation of the reward system (Dženopoljac, 2008).

\section{EMPLOYEE MOTIVATION - IRM BOR}

Practical research within this paper was conducted by applying data collection methods through interviews, surveys and observations as well as analyzing the content of relevant sites, legal regulations, reports and regulations.

The Institute of Mining and Metallurgy Bor (IRM) is a scientific research institution that operates in accordance with the following basic legal acts: The Law on Scientific Research, the Rulebook on the Procedure and Manner of Evaluation and Quantitative Expression of Scientific Research Results and the Rulebook on election to professional titles. The activities of the institute take place within ten organizational units: Office of the Director, Strategic Projects, Department of Legal and Economic Affairs, Integrated Management Systems, Center for Design of Metallic Minerals, Center MEGA, Center for Development Technologies in Metallurgy, Center for Laboratories, Center for science and the Center for Electronic Business Informatics (https://irmbor.co.rs/o-nama/zaposleni/). 
Since its founding in 1962, IRM Bor has undergone various minor or major organizational changes, the most significant of which are the following:

- Organizational development that took place through continuous expansion of activities during the 80's (expansion of activities successively introduced new areas of business such as informatics, construction, architecture, geology, engineering and marketing).

- Organizational transformation into a state institute in 2007, when IRM Bor was constituted as a scientific research institution that operates in accordance with the regulations governing the legal status of public services in the Republic of Serbia.

IRM Bor employs a total of 194 workers, of which 24 doctors of science with an elective title, 29 young doctoral students at state faculties of technical direction, as well as at faculties abroad, 67 engineers and other employees with secondary professional occupations. All doctoral students are funded by the institute, which specializes through working types of training and seminars and other employees.

This educational structure of IRM Bor is very specific in the context of motivation for organizational change. It is an employee structure that requires a particularly sophisticated and balanced approach when it comes to motivation for ongoing work activities and projects as well as for planned organizational changes. That is why such an organization creates and nurtures special organizational communication, culture and special human resources management, as special aspects of motivating employees to work and change.

As for the organizational communication in IRM Bor, it is good, both when it comes to work activities, and when changes in the organization are planned and implemented. Communication is predominantly assertive and two-way, and as such increases the motivation of employees in IRM Bor where they communicate verbally in meetings, colleges and through direct conversations, and written via e-mail and internal password system as well as through the bulletin board.

When it comes to organizational culture, IRM Bor builds and nurtures mostly a culture of achievement (results-oriented, personal initiative and willingness to work hard) and an adaptive culture (which emphasizes creativity, innovation, risk-taking, initiative and entrepreneurship). Accordingly, it can be concluded that the organizational culture is motivating and suitable for introducing changes.

Management at IRM Bor is quite stimulating in terms of motivating employees to work and change. The activities that receive the most attention, in order to maintain and increase employee motivation, are employee development and rewarding. Regarding remuneration in IRM Bor, material rewards in the form of salaries presuppose opportunities for the development of employees and their advancement in scientific, research and professional titles. This means that the management of this organization, both materially but largely by intangible rewards, motivates its employees.

In addition to an efficient salary system harmonized with regulations at the national level, the most important forms of tangible and intangible rewards, as well as motivating employees in the practice of human resources management in IRM Bor are:

- Approval of funds and leave for employees during the attendance of lectures on master's and doctoral studies and the preparation of master's theses and doctoral theses.

- Organizing participation in seminars and conferences ("October Conference").

- Publishing professional and scientific papers in journals ("Mining Works", "Copper").

- Possibility to use the extensive library fund in the field of mining and metallurgy.

- Opportunity to participate and gain knowledge and experience in domestic and foreign projects (EU projects, projects of the Ministry of Education and Science of Serbia and projects intended for the economy).

- Opportunity to participate in the development of innovations (innovative activities in the field of mining and metallurgy are practiced within organizational units: Center for Development Technologies in Metallurgy, Center for Laboratories and Center for Science).

\section{SURVEY ON EMPLOYEES' ATTITUDES TOWARDS MOTIVATION IN IRM BOR}

Practical research of employees' attitudes on motivation for engagement in IRM Bor was conducted through a survey and questionnaire compiled on the basis of searched electronic data sources and examples used in similar previous research. It is based primarily on a proven methodology for testing and measuring the degree of employee engagement, which is directly related to their motivation. The methodology was developed by a respectable Gallup center and it involves questioning through a questionnaire that has been widely known and recognized for years under the name Gallup's 12 questions (Gallup Q12). This questionnaire, based on the reviewed literature on this topic, was slightly corrected for the purpose of our research and supplemented with a few more questions. Questions no. 3, 14 and 15 in the questionnaire were added. 
The survey was conducted on a sample of 50 respondents, employed in IRM Bor. The questionnaire contained 6 generals and 15 special questions grouped into four parts according to the types of needs of employees: basic, individual, team and developmental. It required a simple answer to the questions with Yes, Yes / No or No.

The obtained answers served to, depending on the level of satisfaction of individual needs of employees and their consequent motivation, after the analysis, be classified into one of the following three groups:

- engaged / motivated,

- insufficiently engaged / insufficiently motivated and

- uncommitted / unmotivated.

The questionnaire, which was forwarded to the respondents in printed form, had the following appearance and content:

\section{QUESTIONNAIRE \\ EMPLOYEE MOTIVATION}

The questionnaire in front of you is used to collect data on the motivation of employees in IRM Bor, which will be used exclusively for the purpose of preparing the paper:

Motivation of employees in the process of managing organizational change.

The questionnaire consists of two parts:

I Respondent data (6 questions)

II Attitudes towards motives for engaging in work (15 questions)

The questionnaire is anonymous.

Thanks for your cooperation and help!

\section{RESPONDENT DATA}

Please answer the following questions by typing or circling one option:

\begin{tabular}{llllll}
\hline Gender (M / F): & & & & \\
\hline Age: & -30 & $30-40$ & $40-50$ & $50-60$ & $60+$ \\
\hline Years of service: & -5 & $5-10$ & $10-20$ & $20-30$ & $30+$ \\
\hline Professional qualifications: & Medium & Higher & High & MSc & PhD \\
\hline Title: & Untitled & Professional & Research & Scientific \\
\hline
\end{tabular}

Workplace / Function 


\section{ATTITUDES TO MOTIVATIONS FOR ENGAGEMENT AT WORK}

Please answer the questions by entering the number 1 in one of the empty columns:

\begin{tabular}{|c|c|c|c|c|}
\hline & QUESTIONS & Yes & Yes /No & No \\
\hline I & BASIC NEEDS & & & \\
\hline
\end{tabular}

2. Do you have all the equipment and materials to do the job properly?

3. Do you have other necessary conditions for doing the job correctly?

\section{INDIVIDUAL NEEDS}

4. Do you have the opportunity to do what you do best at work?

5. Do you often receive recognition / praise for a job well done?

6. Does your superior, or colleague, care about you as a person?

7. Is there someone in the workplace who encourages your development?

\section{TEAM NEEDS}

8. Is your opinion taken into account at work?

9. Do you feel that your job is important because of the mission of your organization?

10. Are your associates committed and do their job well?

11. Do you have any of your best friends at work?

\section{DEVELOPMENT NEEDS}

12. Has anyone at work, in the last six months, talked to you about your progress and

12. development?

13. In the last year, have you had the opportunity to progress and develop at work?

14. Are you just in the phase of some form of advancement at work?

15. Have you achieved any form of progress and development in any previous period?

Of the 55 printed questionnaires made available to employees, the questionnaire was duly completed by 50 employees. Respondents provided answers to most of the questions asked. After receiving the answers, the sample of respondents who filled in the questionnaire was analyzed first.
Then, all their answers were analyzed in detail: individual, answers by groups of employee needs and answers at the level of the entire questionnaire. The part of the performed analysis that served as the final conclusions is shown in the following table. 


\begin{tabular}{|c|c|c|c|c|c|c|}
\hline Questions & $\begin{array}{c}\text { Yes } \\
\text { Number of } \\
\text { responses }\end{array}$ & $\begin{array}{c}\text { Yes/No } \\
\text { Number of } \\
\text { responses }\end{array}$ & $\begin{array}{c}\text { No } \\
\text { Number of } \\
\text { responses }\end{array}$ & $\begin{array}{c}\text { Yes } \\
\%\end{array}$ & $\begin{array}{c}\text { Yes/No } \\
\%\end{array}$ & $\begin{array}{c}\text { Yes/No } \\
\%\end{array}$ \\
\hline I group & 105 & 30 & 15 & 70 & 20 & 10 \\
\hline 1. & 30 & 16 & 4 & 60 & 32 & 8 \\
\hline 2. & 35 & 10 & 5 & 70 & 20 & 10 \\
\hline 3. & 40 & 4 & 6 & 80 & 8 & 12 \\
\hline II group & 120 & 60 & 20 & 60 & 30 & 10 \\
\hline 4. & 39 & 6 & 5 & 78 & 12 & 10 \\
\hline 5. & 30 & 17 & 3 & 60 & 34 & 6 \\
\hline 6. & 30 & 18 & 2 & 60 & 36 & 4 \\
\hline 7. & 21 & 19 & 10 & 42 & 38 & 20 \\
\hline III group & 100 & 70 & 30 & 50 & 35 & 15 \\
\hline 8. & 30 & 19 & 1 & 60 & 38 & 2 \\
\hline 9. & 23 & 15 & 12 & 46 & 30 & 24 \\
\hline 10. & 30 & 16 & 4 & 60 & 32 & 8 \\
\hline 11. & 17 & 20 & 13 & 34 & 40 & 26 \\
\hline IV group & 160 & 30 & 10 & 80 & 15 & 5 \\
\hline 12. & 43 & 5 & 2 & 86 & 10 & 4 \\
\hline 13. & 38 & 8 & 4 & 76 & 16 & 8 \\
\hline 14. & 40 & 7 & 3 & 80 & 14 & 6 \\
\hline 15. & 39 & 10 & 1 & 78 & 20 & 2 \\
\hline In total & 485 & 190 & 75 & 65 & 25 & 10 \\
\hline
\end{tabular}




\subsection{CONCLUSIONS AND PROPOSALS FOR IMPROVING THE PRACTICE OF MOTIVATION IN IRM BOR}

By analyzing the sample of IRM employees who filled in the questionnaire within the conducted survey, it was determined and concluded that it is sufficiently representative.

Regarding the sample size, the number of respondents is in relation to the total number of employees in the organization, about $27 \%$, which is a relatively large coverage that contributes to representativeness.

The structure of the sample according to age consists mainly of employees between 40 and 60 years of age. According to the years of work experience, the sample included the most employees with 20 to 30 years of experience. According to education and title, the sample is dominated by highly educated employees with diplomas and titles of master and doctor of science.

The determined representativeness of the sample and the detailed analysis of the answers to the questions from the questionnaire enabled the adoption of the following general conclusions on the motivation of the employees in IRM Bor:

- The answers to the questions from group I indicate that the basic needs of IRM employees are met in a relatively high percentage, fully in $70 \%$ and partially in $20 \%$ of surveyed employees, and that on this basis their motivation is satisfactory.

- Based on the answers from group II of questions, it can be concluded that the individual needs of employees are fully met in $60 \%$ and partially in $30 \%$ of surveyed employees, which is also consequently related to their relatively high motivation.

- The answers to the questions from group III indicate that the team needs of IRM employees are fully met by $50 \%$ and partially by $35 \%$ of the surveyed employees, and that this also contributes to their general motivation.

- Based on the answers from the IV group of questions, it is concluded that the development needs of employees are met to the greatest extent. They are completely satisfied with $80 \%$, and partially with $15 \%$ of the surveyed employees, which means that this is the biggest motivating factor of employees.

At the level of the entire questionnaire, it can be concluded that IRM Bor employees are generally well motivated to engage in work and for organizational changes. $65 \%$ of them answered affirmative on the questions about meeting needs that are directly related to their motivation. $25 \%$ of employees are partially motivated, while, according to the total number of negative answers, only $10 \%$ are unmotivated employees.
With all the limitations and shortcomings of this research, based on its findings, several measures can be proposed that would in the future work of IRM Bor contribute to increasing employee motivation for work and organizational change:

- Continuous monitoring and improvement of working conditions;

- Improving project organization and teamwork culture;

- Continuous monitoring and encouragement of employee development.

\section{CONCLUSION}

Motivation for change is a critical moment of managing organizational change without which all the activities of the process that precede it lose their meaning and the others that follow cannot be successfully implemented.

Special findings based on the conducted research refer to the conclusions regarding certain aspects of the process of motivating members of the organization for organizational change:

- Motivating members of the organization for organizational change is impossible without good organizational communication. Assertive communication is the most adequate type of communication to motivate employees for organizational change.

- Motivating members of the organization for organizational change is impossible without a good organizational culture. Adaptive organizational culture is the most fertile basis for motivation and realization of organizational changes.

- Motivating members of the organization for organizational change is impossible without good human resource management. The motivation of employees for organizational changes is most significantly influenced by the activities of the human resources management process related to the development and rewarding of employees.

In IRM Bor, the important aspects of motivating employees for work and organizational changes are at a relatively satisfactory level. Prevailing assertive communication, and a predominantly adaptive organizational culture, along with adequate human resource management that cares about employee development and reward, are a good basis for the smooth implementation of organizational change.

The results of the survey indicate that employees are well motivated to commit to work and thus to organizational changes: $65 \%$ of respondents are motivated, $25 \%$ are relatively motivated, while only $10 \%$ are unmotivated. 
Based on the previous findings, it can be finally concluded that the motivation of employees in the process of organizational change management is a critical factor on which the successful outcome of the whole process depends. Accordingly, the following recommendations are given for future theorists and practitioners in this field:

- Research should focus on proving even more convincingly the crucial importance of employee motivation in the process of managing organizational change.

- Certain aspects of motivation for organizational change should be further studied and each of these aspects should be broken down to the level that practitioners can understand and apply them as easily as possible.

- In the practice of organizations that initiate the process of organizational change, motivation must be recognized in the right way, from all aspects and in accordance with its importance.

\section{LITERATURE}

Cvetković, M. (2014), Nematerijalna i unutrašnja motivacija zaposlenih u savremenim organizacijama, Master rad, Singidunum Beograd

Džamić, V. (2016), Organizaciono ponašanje i korporativna kultura, Singidunum Beograd

Dženopoljac, V. (2008), Upravljanje promenama - Pristup ljudskih resursa, https://www.slideshare.net/bsckragujevac/vladimir-denopoljac

Gilley, A., Gilley, J. \& McMillan, H. (2009), Organizational change: Motivation, communication, and leadership effectiveness, Performance improvement quarterly, 21(4) PP.75-94 \& 2009 International Society for Performance Improvement, Published online in Wiley InterScienceDOI:10.1002/piq.20039

Grubić, L. (2011), Preduzetničko liderstvo i upravljanje organizacionim promenama u malim i srednjim preduzećima, Master rad, Singidunum Beograd https://irmbor.co.rs/o-nama/zaposleni/ 